\title{
Cultivation Methods of Craftsmanship Spirit under the Integra- tion between Industry and Education
}

Tiantian Shi*

Wenzhou Business College, Wenzhou 325035, Zhejiang province, China. E-mail: wzbc@wzbc.edu.cn

Abstract: In the context of the epidemic and the deepening of China's internationalization, the importance of higher vocational education in the education system has become increasingly prominent, which encourages people of many fields to explore methods to cultivate students' craftsmanship spirit under the integration between industry and education. The government and schools need to take the lead in making proposals for innovation of the integration between industry and education. The industry, enterprises, society, many teachers and students need to participate in it, achieving the implementation of policies and systems, active innovation, and the balance of "teaching" and "training". This paper mainly involves the practical methods of craftsmanship spirit under the integration between industry and education from four aspects: specialty setting, vocational concept, educational fund and cultivation mode.

Keywords: Higher Vocational Education; Integration between Production and Education; Craftsmanship Spirit; Cultivation Mode

\section{Contemporary connotation and research significance of craftsmanship spirit}

Craftsmanship spirit is an indispensable spiritual driving force for social development. Therefore, it is necessary to clarify the contemporary connotation and research significance in order to explore the cultivation methods.

\subsection{The contemporary connotation}

The integration between industry and education is a training mode for schools and enterprises and guided by the national strategies. In this mode, the craftsmanship spirit is a dedicated spirit of being willing to study, being moral and loving the job, and also it is a high level of self-cultivation, moral character and professional value orientation.

\subsection{The research significance}

In 2020, the COVID-19 epidemic was rampant, the economy was hit hard, and the employment pressure was increasing. The government implemented a series of policies, especially in the field of higher vocational education, such as continuously promoting the reform of "three education reform". By expanding the enrollment of higher vocational education, all these are aimed at stabilizing social development and cultivating the students of all-round development. In 2020 and 2021, the number of higher vocational education students increased by about 2 million, and notable achievements were made in the reform of vocational education. With the increase in the number of students, while we pursue to expanding scale of vocational education, we should pay more attention to the improvement of the quality of education and the change in the demand for workers in various regions. Adhering to the integration between industry and education and deepening reform of the integration between industry and education have become a problem that we

This is an open-access article distributed under the terms of the Creative Commons Attribution Non-Commercial License (http://creativecommons.org/licenses/by-nc/4.0/), which permits unrestricted non-commercial use, distribution, and reproduction in any medium, provided the original work is properly cited. 
ought to pay long-term attention.

\section{The practical problem of the cultivation methods of craftsmanship spirit under the background of the integration between production and educa- tion}

Because both school and society levels are crucial in the mode, the cultivation of craftsmanship spirit needs to be analyzed from two aspects.

\subsection{Schools}

Each school has different teachers, supporting policies, training programs, etc., so there will be some differences in the funding situation between schools. Colleges and universities, some of them, will appear less policy support, high tuition, thus affecting the teaching staff and quality. According to data from the China Higher Vocational Development Think Tank, as of September 11, 2020, the median budget of 456 public vocational colleges in China varies significantly between provinces and within the same province, which indicates that there are regional differences in the level of funding.

In order to train craftsmen of big countries and promote the recovery and rise of economy, it is imperative to fully mobilize all available resources of higher vocational education, increase investment in education and maintain the balanced development of higher vocational education in different regions, instead of cultivating students in isolation.

At present, many higher vocational colleges are deficient in the construction of campus culture, the students' overall quality is not enough high, the weak initiative for study represents the lack of campus culture construction ${ }^{[1]}$.

Generally speaking, the level of teachers is insufficient. There are few double-position teachers in higher vocational colleges, the teacher recruitment system needs to be updated, and the first-rate recruitment system has not been formed comprehensively.

Funding is the key to the development of a school. If the fund is not fully used, it will affect the development in every regard. On the whole, higher vocational colleges are not well funded. The underutilization of funds, the phenomenon of staff seeking profit by power and the expansion of higher vocational education have again increased the pressure of fund expenditure. Therefore, higher vocational colleges need to open up more new channels.

\subsection{Social factors and the effects on students' psychology}

First of all, the concept of pursuing the intake of knowledge and the high degree of academic qualifications permeates many people in contemporary society, which makes a large number of people despise the position of vocational education.

Second, colleges and universities need to focus more on students' mental health, get students to change the way they think about vocational education and motivate them to make the most of their resources.

\section{The realistic methods of cultivating craftsmanship spirit under the background of integration between production and education}

The methods to influence the cultivation of craftsmanship spirit are restricted by the times and need to be developed under the control of the government, which can be divided into three methods: specialty, fund and training mode.

\subsection{Specialty settings}

On the basis of the policy, regarding their own situation as the standard, Schools should increase or decrease the major, and change the number of students. Specialties should be set up in line with schools' own educational level, supporting local development and adapting to the overall development trend of the country. If the employment rate is too low, they should be deleted for urgently needed majors, such as medical treatment, which should be expanded and added. And for a few old or relatively sufficient professionals, the enrollment scale should be adjusted promptly. 


\subsection{Use of educational funds}

The main sources of funds for higher vocational colleges include financial expenditure, tuition fees, financing and income. To solve the fund problem of colleges and universities, we must start from the administrators themselves, the management system and the allocation.

The school strictly defines the financial management mode of the school in accordance with the relevant provisions of the Financial System of Institutions of Higher Learning issued in 2012.

It needs to clear financial budget, financial planning, accounting income and expenditure, to achieve "everything traceable".

Managers need to clarify the quantity of school equipment and other materials, timely statistics and replace equipment, so as to avoid waste, repetition or lack of purchase.

Schools should timely adjust the use of funds for more wood behind fewer arrows, special funds dedicated, and effect.

To open up new channels of capital acquisition, to a certain extent, financing, loans, innovation of various cooperation projects, etc.

We should further balance the educational input of different regions and different kinds of higher vocational colleges.

It needs to innovate training models and strengthening school-enterprise cooperation.

\subsection{The reform of the three education reform systems}

Textbooks, timely organization of scarce and updated textbooks compilation need to be reformed. For newly independent majors, other emerging majors and majors that change greatly with the times, textbooks need to be compiled or updated in time. At the same time, as for the content form of textbooks, Internet + textbooks can be further used to deeply integrate electronic books, online courses and other colorful audio, video and graphics with books, so that teachers can teach or students understand more conveniently ${ }^{[2]}$.

In terms of teachers, flexible and merit-based criteria are adopted to select and hire teachers. Among them, long-term and short-term teaching coexist, focusing on teachers' skills, experience and quality of character, and putting down other requirements for highly skilled talents ${ }^{[3]}$. For some majors that are highly dependent on the updating of teaching content, we can invite some professionals from major enterprises and other institutions to give lectures and publicity or conduct short-term communication and teaching. At the same time, for some excellent teachers, schools can give rewards to enhance teachers' teaching motivation and confidence.

In teaching method, first of all, teaching and practice should be further integrated. Schools need to find or buy appropriate teaching resources, such as teaching equipment and cooperative projects. To use the latest teaching materials, make full use of the network resources, and constantly enrich the teaching content, improve the learning interest; Organize students to study in enterprises in turn, closely link the performance of enterprises with the classroom, closely link the spirit of making perfection more perfect with the cooperation between schools and enterprises, and optimize the existing assessment system. And teaching and cultural construction should be further integrated. Schools should actively carry out a series of extracurricular activities of skills and training to enhance students, interest in learning and creativity. Finally, schools should attach more importance to students' mental health, and constantly strengthen the publicity of vocational education. Higher vocational education lectures or classroom education and other methods are used to enhance students' trust in higher vocational education and schools.

Secondly, schools should innovate cooperation projects and cultivate the sense of cooperation. First of all, we should constantly improve the school-enterprise cooperation projects and stop the cooperation with little achievements in time. Next, strengthening the supervision of both sides and timely evaluation of the project is conducive to the later adjustment and improvement of project quality. Finally, enterprises should be aware of the long-term significance of cooperation with schools, that is, continuously providing talents for the society, increasing the reserve of talents for enterprises, and contributing to the long-term significance of social development. 


\section{Conclusion}

The spirit of craftsmanship is an important guarantee for the development of enterprises and the spiritual power of China's internationalization. The spirit of craftsmanship can not only guarantee students' livelihood, but also become a good atmosphere of the society and promote the prosperity and development of the society. However, nowadays many people lack the spirit of craftsmanship and pursue excessive objectification, which is thought-provoking. Education cannot develop without educational innovation, and there is still a long way to go to foster the spirit of craftsmanship.

\section{References}

1. Jia X. Path selection of cultivating craftsman spirit in vocational colleges from the perspective of integration of industry and education. Vocational and Technical Education 2018; 39: 77 - 8 .

2. Niu J. Research on developing strategies of higher vocational textbooks based on industry standards. Journal of Jinan Vocational College 2020; 12: 18 - 19.

3. Huang W. Research on the construction of teachers in applied universities under the background of the integration between industry and education. Wuhan University of Technology. 